OPEN ACCESS

Edited by:

Petr Smýkal,

Palacký University Olomouc, Czechia

Reviewed by:

Hanno Schaefer,

Technical University of Munich,

Germany

Rosario Schicchi,

University of Palermo, Italy

*Correspondence:

Francesco Carim

francesco.carimi@ibbr.cnr.it

Specialty section:

This article was submitted to

Plant Breeding,

a section of the journal

Frontiers in Plant Science

Received: 31 October 2019

Accepted: 18 March 2020

Published: 29 April 2020

Citation:

Pasta S, La Rosa A, Garfi G. Marcenò C, Gristina AS, Carimi F and

Guarino R (2020) An Updated

Checklist of the Sicilian Native Edible

Plants: Preserving the Traditional Ecological Knowledge of Century-Old

Agro-Pastoral Landscapes.

Front. Plant Sci. 11:388.

doi: $10.3389 /$ fpls.2020.00388

\section{An Updated Checklist of the Sicilian Native Edible Plants: Preserving the Traditional Ecological Knowledge of Century-Old Agro-Pastoral Landscapes}

\author{
Salvatore Pasta ${ }^{1}$, Alfonso La Rosa ${ }^{2}$, Giuseppe Garfi', Corrado Marcenò ${ }^{3}$, \\ Alessandro Silvestre Gristina ${ }^{1}$, Francesco Carimi $^{1 *}$ and Riccardo Guarino ${ }^{4}$ \\ ${ }^{1}$ Institute of Biosciences and Bioresources (IBBR), National Research Council of Italy (CNR), Palermo, Italy, ${ }^{2}$ Cooperativa \\ Silene, Palermo, Italy, ${ }^{3}$ Department of Botany and Zoology, Faculty of Science, Masaryk University, Brno, Czechia, \\ ${ }^{4}$ Dipartimento STeBiCeF, Sezione Botanica, University of Palermo, Palermo, Italy
}

The traditional use of native wild food plants (NWFP) may represent a valuable supplementary food source for the present and future generations. In Sicily, the use of wild plants in the human diet dates back to very ancient times and still plays an important role in some rural communities. Moreover, in this regard, the natural and cultural inheritance of this island is wealthy and diversified for several reasons. First, Sicily hosts a rich vascular flora, with 3,000 native and 350 endemic plants. Second, due to its central position in the Mediterranean, the island has acted as a veritable melting pot for the ethnobotanical knowledge of the rural communities of the entire basin. We reviewed all the available literature and, starting from such omnicomprehensive checklist, partially improved thanks to the data issuing from recent field investigations, we critically revised the whole species list, basing our review on field data issuing from interviews and on our expert knowledge. As a result, we provide a substantially updated list of 292 NWFP growing on the island. Further 34 species, reported as NWFP on previous papers were discarded because they are not native to Sicily, while 45 species were listed separately because their identity, occurrence and local use as food is doubtful and needs to be further investigated. Moreover, we tried to shed light on the ecology (growth form and preferential habitat) of the Sicilian NWFP, with special focus on crop wild relatives (CWR). Our preliminary ecological analyses point out that a high percentage of these plants are linked with the so-called 'cultural' landscapes, patchy semi-natural environments rich in ecotones, leading to the conclusion that the maintenance of century-old agro-pastoral practices may represent an effective way to preserve the local heritage of edible plants. Our study allowed to identify as much as 102 taxa of agronomic interest which could be tested as novel crops in order to face ongoing global changes and to comply with sustainable agriculture policies. Among them, 39 taxa show promising traits in terms of tolerance to one or more environmental stress factors, while 55 more are considered CWR and/or can be easily cultivated and/or show high productivity/yield potential.

Keywords: ethnobotany, agro-pastoral landscapes, sustainable agriculture, TEK (traditional environmental knowledge), Ellenberg Indicator Values (EIV) 


\section{INTRODUCTION}

Sicily is the largest Mediterranean island (Figure 1), with an extension of c. $25,400 \mathrm{~km}^{2}$. Its territory is predominantly hilly or mountainous, with less than $20 \%$ of its surface below $300 \mathrm{~m}$ a.s.l. The geographical position of Sicily, its complex geological history (Carbone et al., 2018) and the sharp topographic, edaphic and climatic contrasts make this island one of the most heterogeneous Mediterranean territories. Moreover, Sicily and its satellite islands belong to the Tyrrhenian area, one of the main hot-spots of plant diversity in the whole Mediterranean basin (Médail and Quézel, 1999). Its rich flora counts about 3,000 native plant taxa, around $12 \%$ of which are endemics (Guarino and Pasta, 2018).

Thanks to its location, Sicily has also been a major pathway of human migration, acting as a cultural, economic and ethnic crossing point and melting pot. Human presence in Sicily knows no pauses since 14-13 thousand years ago (Mannino et al., 2012), and with no doubt during this long time-lapse entire plant assemblages have been profoundly shaped by hunters-gatherers, and subsequently even wiped out by the early onset of agrosilvopastoral practices (Leighton, 1999; Tinner et al., 2016).

The vegetation of the island shows almost everywhere the traces of long-lasting land exploitation; not surprisingly, anthropogenic plant communities (Artemisietea vulgaris, Chenopodietea, Papaveretea rhoeadis, Parietarietea judaicae, Poetea bulbosae, and Polygono-Poetea, etc.) characterize almost $50 \%$ of the island's vegetation (Guarino and Pasta, 2017). Furthermore, hard-wheat crop fields currently occupy a large portion of the island's territory, and other traditional forms of dry-land farming (olive, almond, carob tree, pistachio, ashtree, hazelnut, and chestnut groves) still characterize part of the Sicilian rural landscape. Along with the disappearance of traditional practices (e.g., seasonal transhumance) and crafts (e.g., charcoal burners, pipe manufacturers, cork and sumac gatherers, miners, millers, etc.), also many man-made landscapes and habitats, such as dry-stone terraces, fruit orchards, dry-land groves and fallows are fading or have already disappeared. Abandonment and land-use changes are responsible for the fast collapse of local natural and cultivated plant richness (La Mantia et al., 2011; Albrecht et al., 2016). Currently, those traditional landscapes and many others suffer from abandonment or, worse, undergo deep transformations due to agricultural intensification and urban sprawl. Intensive cultivations already cover around $25 \%$ of the island's surface, and they are still expanding. Two blatant examples are the ongoing replacement of Citrus orchards with greenhouses, while intensive vineyards are gradually substituting dry groves. Mechanized agricultural practices and the massive input of chemical fertilizers and pesticides select the weeds, to the detriment of Mediterranean plants and archaeophytes and favoring plenty of non-native tropical and subtropical species, which also take advantage of high nutrientand water input (Guarino et al., 2015).

In respect to this scenario and considering the challenges related to future global climate changes, Sicilian native wild food plants (from now on NWFP) could play a significant role with respect to the fulfillment of both sustainable agriculture and dietary supplement. In addition to raising awareness on the importance of Mediterranean diet (Willett, 2006; Gamboni et al., 2012), there are many other good reasons to go on with the investigation and valuation of the ethnobotanical knowledge on NWFP throughout the Mediterranean area (Guijt, 1998). In fact, during the last 20 years, an increasing number of scientific papers (e.g., Grivetti and Ogle, 2000; Trichopoulou et al., 2000; Simopoulos, 2004; Pieroni and Price, 2005; Schaffer et al., 2005; Bharucha and Pretty, 2010; Ranfa et al., 2014; Disciglio et al., 2017; Renna, 2017) highlighted the strong correlation between wild food consumption and health.

An increasing amount of field data highlights the fact that the Mediterranean countries were not only important as a target of the spread of the so-called 'Neolithic revolution' but played an active role in the early cultivation of the wild ecotypes of several woody species, such as Olea europaea (Diez et al., 2015), Ceratonia siliqua (Viruel et al., 2019), and Vitis vinifera (De Michele et al., 2019), as well as of many vegetables (e.g., Allium spp., Brassica spp., Cynara spp., etc.) and cereal crops (e.g., Avena spp., Hordeum spp., and Triticum spp.), even far before than expected (Snir et al., 2015). The current change of paradigm about the history and geography of early agriculture underlines the importance of studying, conserving and effectively exploiting the germplasm of Mediterranean CWR.

In this paper, we aimed to critically review the so far available lists of traditional Sicilian NWFP, and to provide a first evaluation of the ecological requirements of these plants, paying special attention to the natural and semi-natural ecosystems where they grow and stressing the importance of managing and maintaining them in view of the ongoing global changes. These ecosystems represent important potential reservoirs of food because they host most of the NWFP and many CWR. Additionally, we evaluated some ecological features of NWFP that could be retained as traits of interest for the detection of novel crops and/or the improvement of the existing ones. These plants may help to face the future challenges of Mediterranean agriculture due to global change, such as extreme heat events, water shortage, salinization and adaptation to nutrient-poor soils.

\section{MATERIALS AND METHODS}

\section{Data Set}

The list of the Sicilian NWFP provided by Pasta et al. (2011), based on a critical review of the whole regional ethnobotanical literature concerning edible plants up to 2010, was improved and updated by consulting all the most recent and authoritative works on this topic, i.e., Arcidiacono (2016), Schicchi and Geraci (2016), Morreale (2018), and Geraci et al. (2018). Coria (1989), Lentini and Mazzola (1998), Arcidiacono et al. (2007, 2010), as well as all the Sicilian papers published after 2010, i.e., Aleo et al. (2013), Tuttolomondo et al. (2014a,b), Mazzola et al. (2015), Signorello (2015), Licata et al. (2016), Quave and Saitta (2016), Schicchi and Geraci (2016), Cucinotta and Pieroni (2018), Gargano et al. (2018), and Monello (2018) were consulted, too.

The works of Ghirardini et al. (2007) and Guarrera and Savo (2016) were used as basic reference for the whole Italian territory. The assessment of the native status of the Sicilian edible plants 


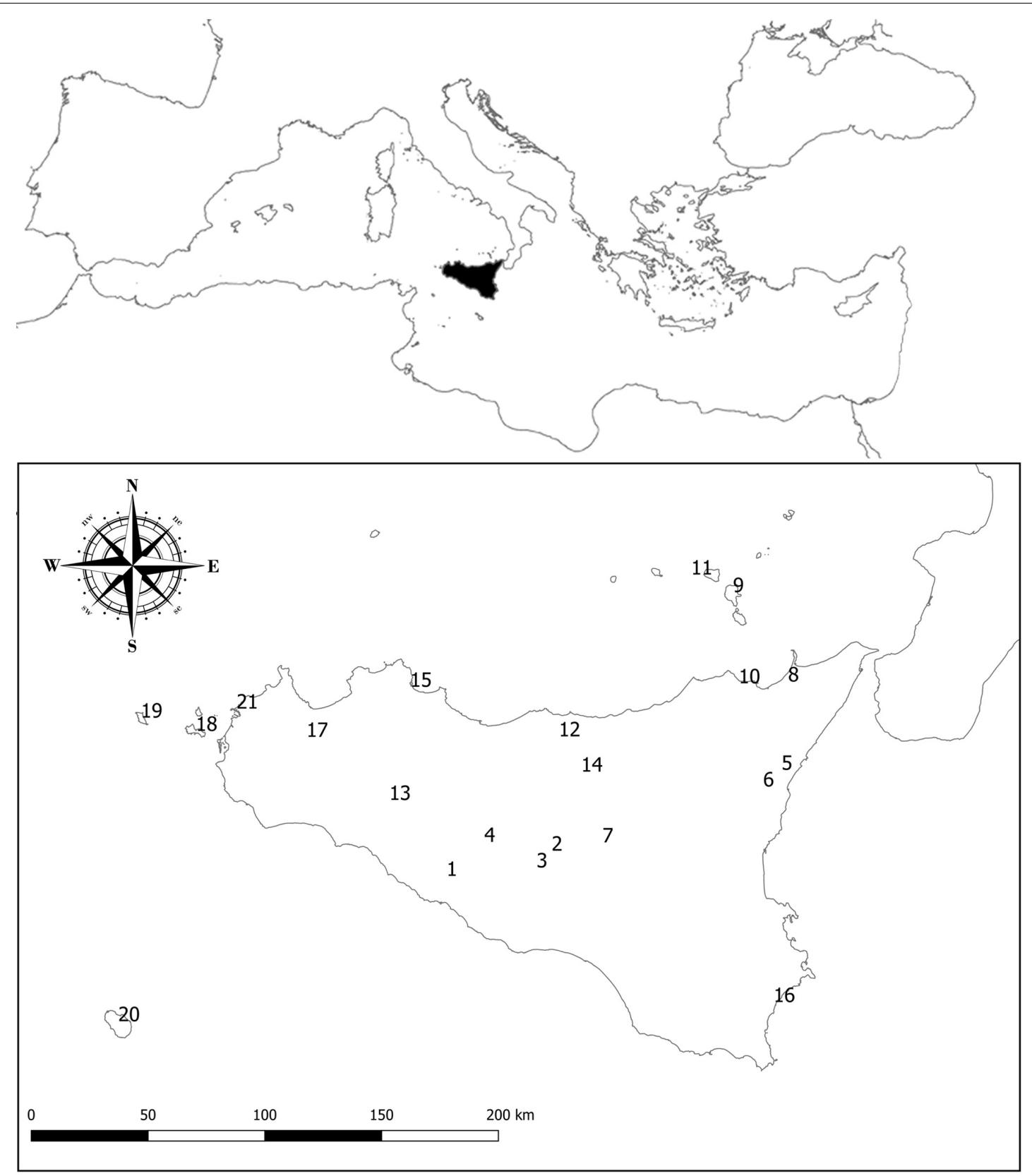

FIGURE 1 | Sicily (black) and its position in the Mediterranean Basin. The numbers refer to the localities where interviews were carried out in order to perform an additional assessment of the harvest frequency of Sicilian NWFP and to update the available knowledge on their use (see Supplementary Table S1), i.e., Joppolo Giancaxio (1), Caltanissetta (2), San Cataldo (3), Sutera (4), Piedimonte Etneo (5), Sant'Alfio (6), Pergusa (7), Barcellona Pozzo di Gotto (8), Lipari Island (9), Patti (10), Salina Island (11), Castelbuono (12), Chiusa Sclafani (13), Gangi (14), Palermo (15), Avola (16), Calatafimi (17), Favignana Island (18), Marettimo Island (19), Pantelleria Island (20), and Trapani (21).

was mostly based on Galasso et al. (2018), and non-native food plants were not taken into account for further elaborations. For each considered taxon, we reported the scientific name according to the second edition of the Flora of Italy (Pignatti et al., 20172019), the synonym(s) encountered in the consulted literature on NWFP, and the plant family according to Chase et al. (2016), while their growth form was assessed according to Pignatti et al. (2017-2019). We decided to skip the analysis of the life forms and chorotypes of the Sicilian NWFP and we provided just basic information concerning other interesting ethnobotanical issues, such as edible part(s) and traditional use(s) as food, because all these topics have been already treated in the most recent and comprehensive papers concerning Sicilian edible plants (Lentini and Venza, 2007; Pasta et al., 2011; Geraci et al., 2018). Basic information on the potential risks induced by toxic or poisonous compounds contained in the Sicilian NWFP is provided, too. 
Additionally, a preliminary semi-quantitative evaluation of the importance of Sicilian NWFP to local harvesters has been performed by comparing the data reported by Geraci et al. (2018) with those issuing from the interviews carried out across the whole Sicilian territory between 2016 and 2019 (Figure 1).

Finally, we annotated whether the listed NWFP were considered CWR by Heywood and Zohary (1995) or maybe deemed CWR following the definition: 'A crop wild relative is a wild plant taxon that has an indirect use derived from its relatively close genetic relationship to a crop' (Maxted et al., 2006).

\section{Ecological Assessment}

In order to outline the ecological preferences of the Sicilian NWFP, the altitudinal range and the Ellenberg Indicator Values (EIVs) concerning each species, extracted from the database of Pignatti et al. (2017-2019), were adopted.

The preferential habitat types of the Sicilian NWFP were assessed following the list of diagnostic species of phytosociological classes of the European vascular plant communities (Mucina et al., 2016, Appendix S6). The phytosociological classes were associated with the EUNIS habitats recorded from Sicily in Carta della Natura (ISPRA, 2012) according to the crosswalk proposed by Angelini et al. (2009). In order to obtain more clues about the correlation between NWFP and different habitat types, we also used the habitats assigned in the database of Pignatti et al. (2017-2019), which recognizes only 24 habitat types belonging to three main ecological groups, i.e., 'terrestrial,' 'aquatic', and 'anthropogenic.' In both cases, all the habitats where a given species may occur were assigned according to the fuzzy logic, with a numerical score ranging from 0 to 1 . In this way, the fuzzy value was equal to 1 for the stenoecious species, whereas for the dioecious species the fuzzy values resulted to be $>0$ and $<1$ depending on the number of habitats assigned to a species.

We used the non-metric multidimensional scaling (NMDS) analysis to summarize the similarity in habitat composition among NWFP, using Bray-Curtis distance measure to calculate the NWFP distance. This analysis was performed by CANOCO 5 (ter Braak and Smilauer, 2012).

We avoided to correlate the values concerning the relative abundance of edible plants basing on the habitat coverage reported in the already mentioned Sicilian map of EUNIS habitats because we considered that any attempt to do this without a statistically significant amount of plot data may lead to unreliable and even misleading results. In fact, a plant may be very rare or very frequent in a given habitat regardless to the area of occupancy of the habitat itself in the island.

\section{RESULTS}

\section{Inventory of Sicilian NWFP}

A critical and updated inventory is provided and counts a total of 292 Sicilian NWFP (Supplementary Table S1). The taxa are listed in alphabetical order according to their scientific name. Synonyms, plant family, growth form, EIVs, altitudinal range, preferential habitat types, and CWR status are reported. Basic information on edible part(s), raw vs. cooked consumption, potential risks due to toxic or poisonous compounds, importance to local harvesters are provided, too.

According to the data issuing from our field investigations and those published by Geraci et al. (2018), the most commonly harvested Sicilian NWFP are Asparagus acutifolius, Beta vulgaris subsp. maritima, Borago officinalis, Brassica rapa subsp. campestris, Cichorium intybus, Foeniculum vulgare s.l., Sonchus oleraceus and Sonchus tenerrimus, while the less commonly harvested are Centranthus ruber, Narcissus tazetta s.l., Papaver setigerum, Rorippa sylvestris, Rumex crispus, and Tordylium apulum.

Our inventory includes 28 species which should probably be considered as archaeophytes in Sicily, but they are not mentioned in the checklist of the vascular alien flora of Italy (Galasso et al., 2018), and their regional status remains uncertain. The scientific name of these plant taxa is followed by an asterisk in the Supplementary Table S1. Moreover, many species commonly cultivated in Sicily and sometimes spreading from cultivations into semi-natural habitats were also taken into account, because palaeobotanical records testify that they occurred in Sicily throughout the Holocene. Hence, their native status cannot be discarded, even if their current distribution does not mirror the distribution range of their original wild populations. This is the case of Castanea sativa, Celtis australis, Ceratonia siliqua, Corylus avellana, Ficus carica, Laurus nobilis, Mespilus germanica, Olea europaea, Pinus pinea, Sorbus domestica, and Vitis vinifera.

On the contrary, a set of 34 plant species, despite being mentioned in the Sicilian ethnobotanical literature, were not considered in our analyses because they are not native (23 archaeophytes and 11 neophytes, see Supplementary Table S2). We also treated as archaeophytes several species which are native to other Italian regions but have certainly been introduced by man in Sicily. This is the case of Asparagus officinalis, Rhus coriaria, Ruscus hypophyllum, and Salvia officinalis, never spreading far from rural and disturbed areas, Origanum onites, whose Sicilian distribution range is restricted to the ruins of the ancient Syracuse, and Cercis siliquastrum, recently experiencing some successful colonization even in semi-natural habitats, but always next to the urban areas where it has been introduced.

The list of Sicilian NWFP was revised taking into account also the misleading information contained in some previous studies. In fact, due to identification errors, to the misinterpretation of Sicilian vernacular plant names and/or to the inappropriate inclusion of congeneric species, some authors reported plants which, either: (1) do not occur in Sicily or at least not in the study areas the papers were focused on; (2) have an extremely narrow niche and distribution range, so they could not be considered of any interest for local rural communities; (3) have been assumed to be food plants because they belong to the same genus of some NWFP, but their local exploitation needs to be better documented; (4) sometimes are used in Sicily as healing plants but cannot be used raw as food because they contain stinky, disgusting, toxic or even lethal compounds.

As a result of all the considerations above, 45 wrong, questionable and doubtful records were excluded from our NWFP inventory. These are listed in Supplementary Table S3, 
along with the reasons for the rejection and the source(s) of the wrong/doubtful records.

Indeed, numerous reliable sources attest that Sicilian people harvest and eat at least 30 potentially toxic and 11 poisonous plant species. The Apiaceae (11 taxa) and Polygonaceae (6) account for more than $40 \%$ of them. Other families rich in dangerous food plants are Amaryllidaceae, Asteraceae, Fabaceae, and Ranunculaceae (3 taxa each), and Asphodelaceae, Iridaceae, and Solanaceae (2).

\section{Diversity and Ecology of Sicilian NWFP}

The 292 taxa listed in Supplementary Table S1 belong to 51 plant families; Figure 2 shows the families including more than 5 NWFP. Around $2 / 3$ of the Sicilian NWFP belong to six families only, i.e., Asteraceae (80, i.e., $27.4 \%$ of the whole list), Brassicaceae (39, 13.4\%), Lamiaceae (18, 6.2\%), Fabaceae (18, $6.1 \%)$, Apiaceae (16, 5.5\%), and Rosaceae (16, 5.5\%). The number of species and genera mirrors the overall taxonomic richness of the main NWFP families, except for Fabaceae, which showed rather a low percentage of edible species despite being one of the richest families of the Sicilian vascular flora. None of the Sicilian NWFP belongs to Poaceae, even if this family is the second richest of the Sicilian vascular flora, counting 293 different species on the Island.

If we focus on the five growth forms which count more than 10 Sicilian NWFP, the rosulate edible herbs result proportionally more represented than in the whole regional flora and the same pattern has been observed for climbing herbs and lianas (Figure 3). The percentage of scapose species among wild food plants is slightly higher, whereas that of caespitose and geophytes slightly lower than that of the whole Sicilian flora.

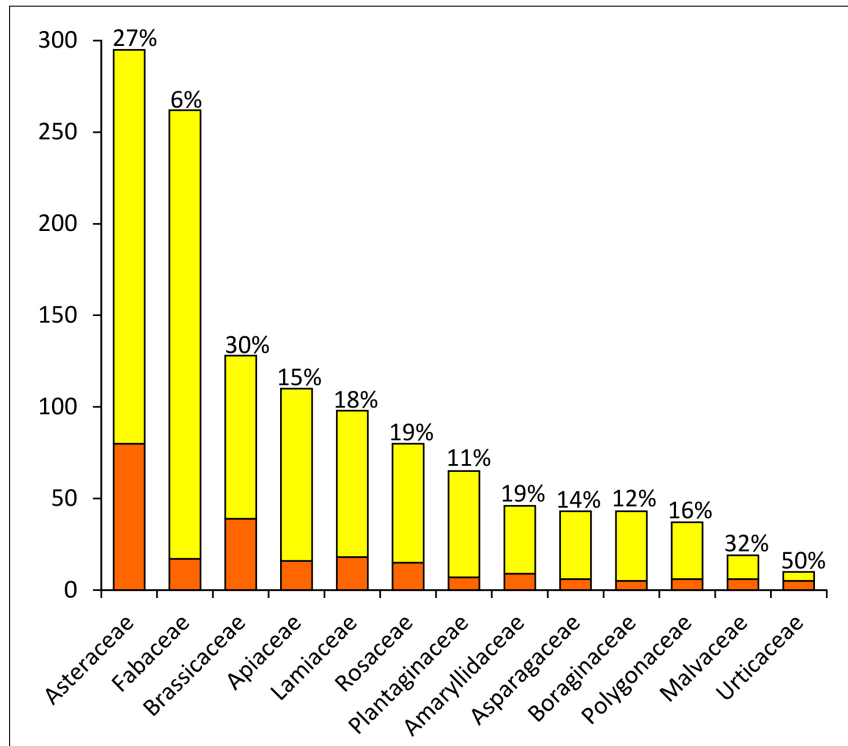

FIGURE 2 | Plant families including more than 5 NWFP in Sicily. Orange: number of NWFP; Yellow: number of non-edible plants. The percentage of NWFP per family is reported on the top of each column.

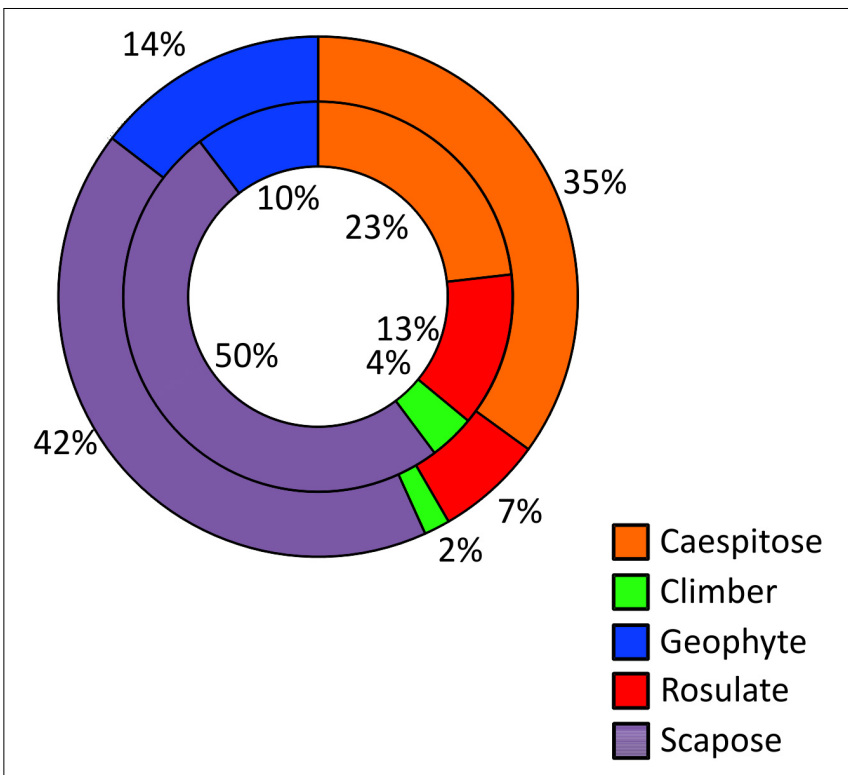

FIGURE 3 | Frequency of the five commonest growth forms among NWFP (inner circle) and in the entire Sicilian vascular flora (outer circle).

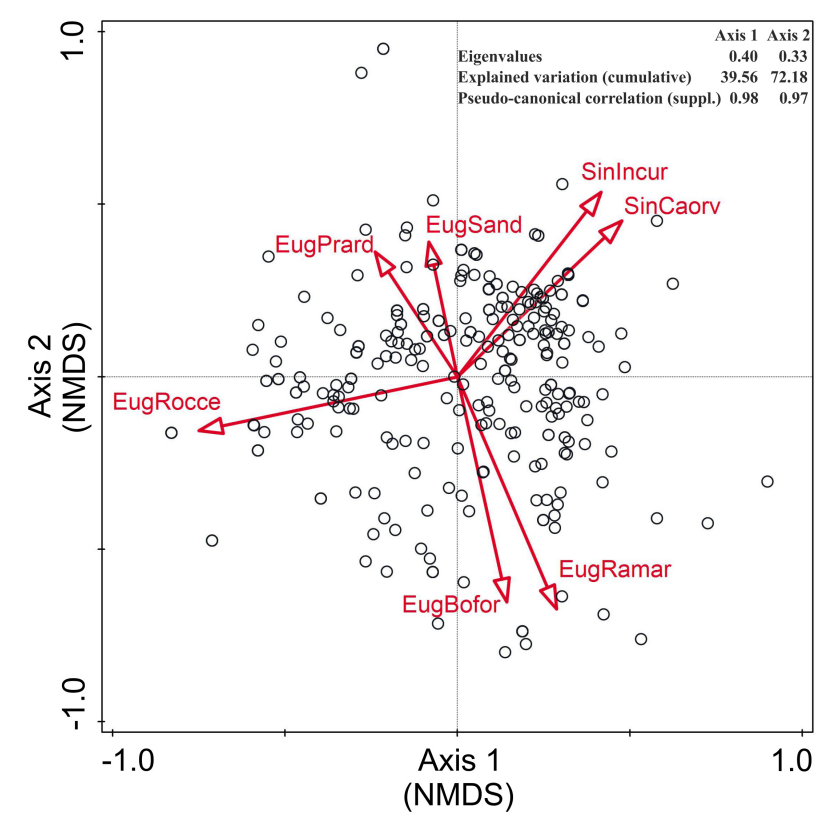

FIGURE 4 | Non-metric multidimensional scaling (NMDS) ordination plot of the NWFP of Sicily with respect to the habitats reported in the Flora of Italy (Pignatti et al., 2017-2019). Only the habitats explaining $>3 \%$ of the total variance are displayed. EugBofor, woodlands and forests; EugPrard, dry grasslands; EugRamar, edges, clearings, deciduous shrubberies; EugRocce, rocks, barks, small outcrops; EugSand, sands; SinCaorv, crops, vegetable gardens, orchards, vineyards, olive groves; and Sinlncur, fallows, ruderal and urban habitats.

The relationship between the NWFP and habitat types is shown in the NMDS ordination plots (Figure 4 and Supplementary Figure S1). In both of the considered habitat 
classifications, most species are concentrated near the center of the graphics, proving to be rather dioecious, with a clear preference for anthropogenic habitats. The first two axes of the NMDS explain $80.7 \%$ (EUNIS) and $72.18 \%$ (Flora of Italy) of the total variance, and in both cases, they appear to be related to a gradient of anthropogenic disturbance and a gradient of edaphic humidity, respectively.

Non-metric multidimensional scaling ordination plots show the prevalence of ruderal-nitrophilous species linked to anthropogenic vegetation and man-made habitats and ecotones, which represent the core of local edible plants. Yet, three further species groups cluster rather clearly: (1) the fruit-bearing woody species linked to forest and shrubland communities, (2) a group rich in chamaephytes and hemicryptophytes adapted to the harsh conditions of bare and nutrient-poor soils mostly occurring in rocky habitats, and (3) a group including many species adapted to sandy or salty soils.

\section{Good Performers and Stress-Tolerant Sicilian NWFP}

As far as EIVs are concerned, some significant differences in the $U_{-}, R-$, and $N$-values of the Sicilian NWFP with respect to the whole regional flora (data not shown) have been detected. In particular, even if the mean values are comparable, the EIVs assigned to the NWFP tend to be less dispersed than those of the regional flora. Based on the EIVs, the Sicilian NWFP displaying the maximum tolerance to heat, drought, soil salinity and adaptation to nutrient-poor soils are reported in Table $\mathbf{1}$. This list includes 39 plant species having good performances under harsh environmental conditions, being able to overcome at least one out of four severe stress factors, i.e., two edaphic (low soil nutrient content and high soil salinity) ad two climatic (lack of water and extreme thermic events). In particular, Capparis species can be considered well adapted to harsh climatic and edaphic conditions (Mercati et al., 2019), with Capparis sicula showing a high ecological plasticity, as it can survive both in poorly aerated, salty and clayey soils as well as in secondary habitats such as roadsides (Gristina et al., 2014), while C. spinosa mainly colonizes coastal rocky cliffs. Wild cabbages (Brassica spp.) can thrive on nutrient-poor soils and tolerate intense heat and water stress growing on base-rich cliffs (from the coastline up to 1,000-1,200 m a.s.1.), while Diplotaxis crassifolia and Thymbra capitata can stand the enduring summer drought stress typical to Mediterranean grasslands and shrublands. Many NWFP belonging to Asteraceae, Brassicaceae, Lamiaceae, Valerianaceae tolerate very low soil nutrient availability and water stress but cannot stand thermal stress. Cakile maritima, Crithmum maritimum, Echinophora spinosa, and Juncus acutus, all growing in coastal habitats, are well adapted to salt-rich soils, the last two being resistant to nutrient-poor soils and only the latter also tolerant to water stress.

\section{Sicilian NWFP and CWR}

Based on literature reviews, we found that as much as 55 Sicilian NWFP (i.e., $18.8 \%$ of the total) are CWR (Table 2). Many of these plant taxa show high interest for their promising agronomic traits and/or for their high stress-tolerance. The richest families in CWR are Brassicaceae (9 taxa), Rosaceae (8), Asteraceae (7), Lamiaceae (6), Fabaceae (5), Apiaceae, and Asparagaceae (4), Amaryllidaceae and Capparaceae (2). With four taxa, the genera Asparagus and Brassica result to be the richest ones, followed by Allium, Capparis, Cichorium, Mentha, Rubus, Salvia, and Sorbus (2 taxa each).

To the family Asteraceae belong the wild progenitors of globe artichoke (Cynara scolymus L.), lettuce (Lactuca serriola L.) and chicories (Cichorium intybus and Cichorium pumilum), while the family Brassicaceae includes different species of wild cabbages (Brassica incana, B. nigra, B. rupestris and B. tournefortii) and wild rockets (Eruca sativa). Lamiaceae count many relatives of common spices such as mints (Mentha spicata and Mentha suaveolens), oregano (Origanum vulgare subsp. viridulum), rosemary (Rosmarinus officinalis), sages (Salvia fruticosa subsp. thomasii and Salvia sclarea). Other noteworthy CWR are the wild fennel (Foeniculum vulgare), wild strawberry (Fragaria vesca), wild garlic (Allium ampeloprasum and Allium commutatum) and wild capers (Capparis sicula and C. spinosa).

\section{DISCUSSION}

\section{A Matter of Natural and Land-Use History}

The landscapes of Sicily are the result of anthropogenic disturbances occurring over several millennia. Through the centuries, rural communities have managed their environment and farmed the land in their natural way, creating a rich diversity of landscapes, choral representation of the historical identity of the territory and human cultural heritage (Guarino and Pasta, 2017, and references therein). One of the first effects of human land use was an increased fire frequency: wildfires were the easiest way to obtain grass-dominated terrains, which could be used as rangelands or, eventually, cultivated. The prevalence of NWFP in semi-natural and anthropogenic habitats could be seen as the result of a process of selection and adaptation lasting since 10,000 years, at least. The plants growing in habitats of this kind are providing most of the harvest, because it is easy to identify them and because they are usually found in dense and homogeneous populations. For instance, the relatively high percentage of rosulate plants among NWFP could mirror their ecological adaptation to grazing disturbance. This growth form enables to reduce the damages (namely defoliation) caused by the bites and by the trampling activity of domestic herbivores ( $\mathrm{Xu}$ et al., 2013, and references therein). Most of the edible climbers, vines and lianas (e.g., Clematis, Lathyrus, Rubia, Smilax, Tamus, and Vicia) are instead common in ecotones, which have been created and shaped by humans.

As far as we know, no literature data is explaining why rosette-bearing and scapose (erect) taxa are more common than caespitose among wild food plants, whereas the relatively low percentage of edible geophytes is likely to depend on the high frequency of poisonous species within this group. As for EIVs, the values of ' $U$ ' (edaphic humidity) of the Sicilian edible plants appear to be relatively low. This pattern matches with 
TABLE 1 | An overview on the Sicilian NWFP which show the best performance with respect to four major stress factors, as suggested by the numerical values of the selected EIVs, i.e., T (temperature, range 1-12), U (edaphic humidity, range 1-11), N (nutrients, range 1-9), and S (salinity, range 0-3).

Taxa which are well adapted to climatic and edaphic stress

Capparis sicula Veill.

Capparis spinosa L.

Lotus cytisoides L.

Taxa which are well adapted to nutrient-poor soils and tolerate thermic and water stress

Astragalus boeticus L.

Biscutella maritima Ten.

Brassica incana Ten.

Brassica rupestris Raf.

Brassica tournefortii Gouan

Carlina gummifera (L.) Less.

Carlina sicula Ten.

Chamaerops humilis L.

Diplotaxis crassifolia (Raf.) DC.

Plantago serraria L.

Rumex bucephalophorus L.

Thymbra capitata (L.) Cav.

Taxa which are well adapted to nutrient-poor and salt-rich soils and tolerant to water stress

Crithmum maritimum L.

Taxa which are adapted to nutrient-poor and salt-rich soils

Echinophora spinosa L.

Taxa which are well adapted to nutrient-poor soils and tolerant to water stress

Centranthus ruber (L.) DC.

Fedia graciliflora Fisch. \& C.A. Mey.

Hyoseris radiata L.

Hyoseris scabra L.

Hypochoeris cretensis (L.) Chaub. \& Bory

Hypochaeris glabra L.

Hypochaeris laevigata (L.) Ces., Pass. \& Gibelli

Hypochaeris radicata $\mathrm{L}$.

Lavandula stoechas L.

Lobularia maritima (L.) Desv.

Micromeria juliana (L.) Benth. ex Rchb.

Papaver setigerum DC.

Phagnalon saxatile (L.) Cass.

Rosmarinus officinalis $\mathrm{L}$.

Thymus spinulosus Ten.

Tolpis umbellata Bertol.

Tolpis virgata (Desf.) Bertol.

Valerianella eriocarpa Desv.

Taxa which are well adapted to nutrient-poor soils

Plantago lagopus L.

Reseda alba L. s.l.

Taxa which are adapted to salt-rich soils

Cakile maritima Scop.

Juncus acutus L.

Number of taxa showing the maximum value of tolerance to the selected stress factors
Scientific name according to Pignatti et al. (2017-2019)

\begin{tabular}{llllll} 
Plant Family (Chase et al., 2016) & $T$ & $U$ & $N$ & $S$ \\
\hline
\end{tabular}

\begin{tabular}{|c|c|c|c|}
\hline Capparaceae & 10 & 2 & 1 \\
\hline Capparaceae & 10 & 2 & 1 \\
\hline Fabaceae & 10 & 1 & 1 \\
\hline Fabaceae & 11 & 1 & 1 \\
\hline Brassicaceae & 10 & 2 & 1 \\
\hline Brassicaceae & 10 & 2 & 1 \\
\hline Brassicaceae & 10 & 2 & 1 \\
\hline Brassicaceae & 12 & 2 & 1 \\
\hline Asteraceae & 11 & 1 & 1 \\
\hline Asteraceae & 11 & 1 & 1 \\
\hline Arecaceae & 10 & 1 & 1 \\
\hline Brassicaceae & 11 & 2 & 1 \\
\hline Plantaginaceae & 10 & 2 & 1 \\
\hline Polygonaceae & 12 & 2 & 1 \\
\hline Lamiaceae & 10 & 2 & 1 \\
\hline Apiaceae & 8 & 1 & 1 \\
\hline Apiaceae & 8 & 4 & 1 \\
\hline Valerianaceae & 8 & 2 & 1 \\
\hline Valerianaceae & 9 & 2 & 1 \\
\hline Asteraceae & 8 & 2 & 1 \\
\hline Asteraceae & 9 & 1 & 1 \\
\hline Asteraceae & 8 & 2 & 1 \\
\hline Asteraceae & 8 & 2 & 1 \\
\hline Asteraceae & 8 & 2 & 1 \\
\hline Asteraceae & 8 & 2 & 1 \\
\hline Lamiaceae & 9 & 2 & 1 \\
\hline Brassicaceae & 9 & 2 & 1 \\
\hline Lamiaceae & 8 & 2 & 1 \\
\hline Papaveraceae & 8 & 2 & 1 \\
\hline Asteraceae & 9 & 2 & 1 \\
\hline Lamiaceae & 8 & 2 & 1 \\
\hline Lamiaceae & 8 & 2 & 1 \\
\hline Asteraceae & 9 & 2 & 1 \\
\hline Asteraceae & 8 & 2 & 1 \\
\hline Valerianaceae & 9 & 2 & 1 \\
\hline Plantaginaceae & 9 & 3 & 1 \\
\hline Resedaceae & 8 & 3 & 1 \\
\hline Brassicaceae & 8 & 6 & 8 \\
\hline \multirow[t]{2}{*}{ Juncaceae } & 8 & 8 & 3 \\
\hline & 2 & 7 & 37 \\
\hline
\end{tabular}

Best responses to one or more stress factors are in bold. 
TABLE 2 | Families of Sicilian NWFP - including CWR and/or stress-tolerant taxa - to be tested in order to detect and develop new crops for their high potential as resources for agronomic, genetic, pharmaceutical, and nutritional purposes.

\begin{tabular}{|c|c|c|c|c|c|c|}
\hline $\begin{array}{l}\text { Family of NWFP } \\
\text { of agronomic } \\
\text { interest }\end{array}$ & $\begin{array}{l}\text { Number of } \\
\text { sp./subsp. }\end{array}$ & $\begin{array}{l}\text { Number of } \\
\text { genera }\end{array}$ & $\begin{array}{l}\text { Number of } \\
\text { CWR }\end{array}$ & CWR & $\begin{array}{l}\text { Other taxa to be tested for } \\
\text { the development of new } \\
\text { crops }\end{array}$ & $\begin{array}{l}\text { Other taxa to be tested for } \\
\text { the development of new } \\
\text { stress-tolerant crops }\end{array}$ \\
\hline Amaranthaceae & 2 & 2 & 1 & $\begin{array}{l}\text { Beta vulgaris L. subsp. } \\
\text { maritima (L.) Arcang. }\end{array}$ & Chenopodium album L. & \\
\hline Amaryllidaceae & 4 & 1 & 2 & $\begin{array}{l}\text { Allium ampeloprasum L. } \\
\text { Allium commutatum Guss. }\end{array}$ & $\begin{array}{l}\text { Allium ursinum L. } \\
\text { Allium triquetrum L. }\end{array}$ & \\
\hline Apiaceae & 6 & 6 & 4 & $\begin{array}{l}\text { Apium graveolens L. } \\
\text { Daucus carota L. s.I. } \\
\text { Foeniculum vulgare Mill. s.I. } \\
\text { Helosciadium nodiflorum (L.) } \\
\text { W.D.J.Koch subsp. nodiflorum }\end{array}$ & & $\begin{array}{l}\text { Crithmum maritimum L. } \\
\text { Echinophora spinosa L. }\end{array}$ \\
\hline Asparagaceae & 6 & 3 & 4 & $\begin{array}{l}\text { Asparagus acutifolius L. } \\
\text { Asparagus albus L. } \\
\text { Asparagus aphyllus L. } \\
\text { Asparagus horridus L. }\end{array}$ & $\begin{array}{l}\text { Muscari comosum (L.) Mill. } \\
\text { Ruscus aculeatus L. }\end{array}$ & \\
\hline Asteraceae & 29 & 19 & 7 & $\begin{array}{l}\text { Cichorium intybus L. } \\
\text { Cichorium pumilum Jacq. } \\
\text { Cynara cardunculus L. s.I. } \\
\text { Lactuca serriola L. } \\
\text { Matricaria chamomilla L. } \\
\text { Scorzonera undulata Vahl } \\
\text { subsp. deliciosa (DC.) Maire } \\
\text { Tragopogon porrifolius L. }\end{array}$ & $\begin{array}{l}\text { Hedypnois cretica (L.) } \\
\text { Dum.Cours. } \\
\text { Hedypnois rhagadioloides (L.) } \\
\text { F.W.Schmidt } \\
\text { Helminthotheca echioides (L.) } \\
\text { J.Holub } \\
\text { Leontodon siculus (Guss.) } \\
\text { Nyman } \\
\text { Leontodon tuberosus L. } \\
\text { Reichardia picroides (L.) Roth } \\
\text { Rhagadiolus stellatus (L.) } \\
\text { Gaertn. } \\
\text { Scorzoneroides cichoracea } \\
\text { (Ten.) Greuter } \\
\text { Scorzoneroides muelleri } \\
\text { (Sch.Bip.) Greuter \& Talavera } \\
\text { subsp. muelleri } \\
\text { Sonchus oleraceus L. } \\
\text { Sonchus tenerrimus L. } \\
\text { Urospermum picroides (L.) } \\
\text { F.W.Schmidt }\end{array}$ & $\begin{array}{l}\text { Carlina sicula Ten. } \\
\text { Hyoseris radiata L. } \\
\text { Hyoseris scabra L. } \\
\text { Hypochaeris cretensis (L.) } \\
\text { Chaub. \& Bory } \\
\text { Hypochaeris glabra L. } \\
\text { Hypochaeris laevigata (L.) Ces., } \\
\text { Pass. \& Gibelli } \\
\text { Hypochaeris radicata L. } \\
\text { Phagnalon saxatile (L.) Cass. } \\
\text { Tolpis umbellata Bertol. } \\
\text { Tolpis virgata (Desf.) Bertol. s.I. }\end{array}$ \\
\hline Betulaceae & 1 & 1 & 1 & Corylus avellana L. & & \\
\hline Brassicaceae & 17 & 11 & 9 & $\begin{array}{l}\text { Barbarea bracteosa Guss. } \\
\text { Brassica incana Ten. } \\
\text { Brassica nigra (L.) Koch } \\
\text { Brassica rapa L. subsp. } \\
\text { campestris (L.) Clapham } \\
\text { Brassica rupestris Raf. s.I. } \\
\text { Eruca sativa Mill. } \\
\text { Nasturtium officinale R.Br. } \\
\text { Raphanus raphanistrum L. s.I. } \\
\text { Sinapis alba L. s.l. }\end{array}$ & $\begin{array}{l}\text { Erucastrum virgatum C.Presl } \\
\text { Rapistrum rugosum (L.) All. } \\
\text { Diplotaxis erucoides (L.) DC. } \\
\text { Diplotaxis muralis (L.) DC. } \\
\text { Diplotaxis tenuifolia (L.) DC. }\end{array}$ & $\begin{array}{l}\text { Cakile maritima Scop. } \\
\text { Lobularia maritima (L.) Desv. } \\
\text { Diplotaxis crassifolia (Raf.) DC. }\end{array}$ \\
\hline Capparaceae & 2 & 1 & 2 & $\begin{array}{l}\text { Capparis sicula Veill. } \\
\text { Capparis spinosa L. subsp. } \\
\text { rupestris (Sm.) Nyman }\end{array}$ & & \\
\hline Ericaceae & 1 & 1 & 0 & & Arbutus unedo L. & \\
\hline Fabaceae & 4 & 4 & 4 & $\begin{array}{l}\text { Ceratonia siliqua L. } \\
\text { Glycyrrhiza glabra L. } \\
\text { Lathyrus cicera L. } \\
\text { Pisum sativum L. subsp. } \\
\text { biflorum (Raf.) Soldano } \\
\text { Vicia sativa L. }\end{array}$ & & \\
\hline Fagaceae & 1 & 1 & 1 & Castanea sativa Mill. & & \\
\hline Iridaceae & 1 & 1 & 1 & Crocus longiflorus Raf. & & \\
\hline
\end{tabular}


TABLE 2 | Continued

\begin{tabular}{|c|c|c|c|c|c|c|}
\hline $\begin{array}{l}\text { Family of NWFP } \\
\text { of agronomic } \\
\text { interest }\end{array}$ & $\begin{array}{l}\text { Number of } \\
\text { sp./subsp. }\end{array}$ & $\begin{array}{l}\text { Number of } \\
\text { genera }\end{array}$ & $\begin{array}{l}\text { Number of } \\
\text { CWR }\end{array}$ & CWR & $\begin{array}{l}\text { Other taxa to be tested for } \\
\text { the development of new } \\
\text { crops }\end{array}$ & $\begin{array}{l}\text { Other taxa to be tested for } \\
\text { the development of new } \\
\text { stress-tolerant crops }\end{array}$ \\
\hline Lamiaceae & 11 & 9 & 6 & $\begin{array}{l}\text { Mentha spicata L. } \\
\text { Mentha suaveolens Ehrh. } \\
\text { Origanum vulgare L. subsp. } \\
\text { viridulum (Martrin-Donos) } \\
\text { Nyman } \\
\text { Rosmarinus officinalis L. } \\
\text { Salvia fruticosa Mill. subsp. } \\
\text { thomasii (Lacaita) Brullo, } \\
\text { Guglielmo, Pavone, and Terrasi } \\
\text { Salvia sclarea L. }\end{array}$ & Clinopodium nepeta (L.) Kuntze & $\begin{array}{l}\text { Lavandula stoechas L. } \\
\text { Micromeria juliana (L.) Benth. ex } \\
\text { Rchb. } \\
\text { Thymbra capitata (L.) Cav. } \\
\text { Thymus spinulosus Ten. }\end{array}$ \\
\hline Lauraceae & 1 & 1 & 1 & Laurus nobilis L. & & \\
\hline Moraceae & 1 & 1 & 1 & Ficus carica L. s.l. & & \\
\hline Oleaceae & 1 & 1 & 1 & $\begin{array}{l}\text { Olea europaea L. var. sylvestris } \\
\text { (Mill.) Lehr. }\end{array}$ & & \\
\hline Rosaceae & 8 & 6 & 8 & $\begin{array}{l}\text { Crataegus monogyna Jacq. } \\
\text { Fragaria vesca L. } \\
\text { Prunus spinosa L. } \\
\text { Pyrus spinosa Forssk. } \\
\text { Rubus idaeus L. } \\
\text { Rubus ulmifolius Schott } \\
\text { Sorbus aucuparia L. subsp. } \\
\text { praemorsa (Guss.) Nyman } \\
\text { Sorbus domestica L. }\end{array}$ & & \\
\hline Urticaceae & 4 & 1 & 0 & & $\begin{array}{l}\text { Urtica dioica L. } \\
\text { Urtica membranacea Poir. } \\
\text { Urtica pilulifera L. } \\
\text { Urtica urens L. }\end{array}$ & \\
\hline Valerianaceae & 1 & 1 & 1 & Valerianella locusta (L.) Laterr. & & \\
\hline Vitaceae & 1 & 1 & 1 & $\begin{array}{l}\text { Vitis vinifera L. subsp. sylvestris } \\
\text { (C.C.Gmel.) Hegi }\end{array}$ & & \\
\hline Total & 102 & 72 & 55 & & & \\
\hline
\end{tabular}

the fact that basing on the bioclimatic classification of Sicily (Bazan et al., 2015), most of the Sicilian NWFP thrive under thermo-mediterranean bioclimatic conditions, characterized by long-lasting summer drought stress. The values of ' $R$ ' and ' $N$ ' indicate that many NWFP prefer base- and nutrient-rich soils, typical to the Sicilian hilly landscapes prone to human (namely agro-pastoral) practices. Interestingly, the high rate of ruderalnitrophilous species among the edible plants appreciated for their fleshy stem or foliage was confirmed in the study carried out in northern Croatia by Vitasović Kosić et al. (2017), who also used EIVs to investigate the ecology of local wild food plants. Moreover, the altitudinal distribution pattern of the Sicilian NWFP (data not shown) suggest that they are slightly more concentrated in the lowlands and hilly areas of the island, where most of the permanent settlements and arable lands are concentrated since millennia.

Non-metric multidimensional scaling provides interesting clues on the spatial and temporal distribution of the food resources afforded by NWFP. For instance, most of the woody species are linked to forests, riverine plant communities and shrublands. They produce large amounts of fruits or berries that can be eaten raw, and represent an important food resource between the end of spring and the end of summer when all the annual and most of the perennial herbaceous NWFP are not available anymore.

Most of the edible Lamiaceae group together and are well adapted to nutrient-poor and rocky habitats (Figure 4 and Supplementary Figure S1), where they cope with water and nutrient shortage by producing many aromatic compounds that play the twofold action of helping them to save water and to inhibit predation by herbivores. Other stress-tolerant plants typical to sandy and/or salty soils form another cluster rich in species adapted to high salt input and long-lasting water shortage.

Under an ecological perspective, nutrient-poor habitats promote selection for traits allowing efficient resource conservation, while nutrient-rich environments select for species with acquisitive trait profiles (Reich, 2014). Domesticated plants, and in particular herbaceous crops, share few common traits and represent a small portion of the phenotypic spectrum displayed by their wild ancestors: the majority of those living on nutrient-rich soils bear soft, large and short-lived leaves, are fast-growing and proficient competitors, with high leaf nitrogen concentration and tall canopies (Freschet et al., 2015; Milla et al., 2018). As cultivation generally involved higher and more regular nutrient and water supply rates, humans probably focused their interest on NWFP bearing resource-acquisition 
trait profiles (Bogaard et al., 2013; Araus et al., 2014). Some of them, like the ancestors of several cereal crops, were chosen because they showed a rapid shift of their functional traits under domestication, being able to invest more energy on leaf biomass and height growth than other wild grasses that were used by hunter-gatherers, but were never domesticated (Cunniff et al., 2014). Many other cultivated plants descend from wild ancestors which were pre-adapted for cultivation thanks to several favoring traits (Triboullois et al., 2015; Martin-Robles et al., 2019). These considerations fit perfectly with the fact that most of the Sicilian NWFP, commonly used as vegetables and concentrated near the center of Figure 4 and Supplementary Figure S1, share many morphological and ecological traits: they colonize nutrient-rich soils and ecotones, they bear large and tender leaves, they grow very fast, they are good competitors.

The massive number of edible Asteraceae (subfam. Cichorioideae) is a common pattern in Mediterranean countries (Della et al., 2006; Leonti et al., 2006; Rivera et al., 2006; Hadjichambis et al., 2008). Interestingly, Cichorioideae appear to be strongly associated with pastoral activities since ancient times (Florenzano et al., 2015). Also, Brassicaceae are an essential component in wild harvesting in south Italian regions (Biscotti et al., 2018). These plants have probably been gathered since the very first stages of agriculture by Neolithic farmers, as they behaved as weeds.

All these ecological clues lead to the same conclusion: the majority of the Sicilian NWFP may be considered as 'old companions' of local human communities. Early Sicilians probably discovered very soon that many 'proto-weeds' colonizing the open spaces created after the disruption of pristine woodlands were useful and tasty, as it has been recently shown also for Israel (Snir et al., 2015). Also, the available palaeoecological studies (Sadori et al., 2008; Stika et al., 2008; Noti et al., 2009; Tinner et al., 2009) suggest that from the beginning of the Holocene $(\sim 10 \mathrm{Ka})$ onward, human impact has been an important - if not the main - factor inducing the final opening of the Sicilian landscape. With their activities (burning, clearing, cutting, farming, plowing, etc.) local Neolithic communities not only fostered the success of many non-native pioneer lightdemanding plants inadvertently introduced with crop species (the so-called 'archaeophytes') but also ended the shaping of the regional natural and semi-natural landscape, giving rise to a complex mosaic of prevalently open habitats with scattered nuclei of woodlands, shrublands and species-rich garrigues and grasslands (Guarino et al., 2005; Guarino, 2006; Brullo and Guarino, 2007).

\section{The Importance of a Multidisciplinary Approach}

An unexpected result of our investigation concerned the detection of 46 wrong, questionable and doubtful plants that cannot be included among the Sicilian NWFP.

There are two distinct groups of experts coping with useful plants, plant uses and plant names: from one side the 'practitioners', such as farmers, shepherds, artisans, cooks, forest workers, fishermen, hunters, etc., from the other side the 'scholars', like ethnobotanists, ethno-anthropologists, philologists, historians, biochemists, veterinaries, etc. Until recent past, these two groups have been hardly sharing their knowledge. This is the main reason why we frequently find plant misidentifications in the papers written by non-botanists, while 'pure' botanists often fail to spell correctly, to trace the root of vernacular names and/or to report adequately the uses of the plants they study. Such 'communication gaps' may cause risky misidentifications due to the transfer of erroneous information concerning the alimentary use and therapeutic properties of some poisonous plants (i.e., Corsi and Pagni, 1979; Provitina, 1991; Atzei, 2003; Giardina et al., 2007; Łuczaj et al., 2012; see Supplementary Table S3).

The use of toxic and poisonous plants is a common pattern worldwide, especially were seasonality strongly affects food availability, and local human communities learned to exploit even the less attracting resources. This fact is not only a consequence of famine but also a question of timing and a result of centuryold folk knowledge: in fact, some plants may contain a much lower concentration of poisonous compounds in some periods of the year and/or in some specific organs. Moreover, the fact that some communities use a species does not necessarily mean it is safe to eat it. Hence, detailed data on the gathering and cooking procedures are of paramount importance, and such information should be taken into account before discarding any poisonous plant from the list of edible ones: this is the case of several species which are cooked before being consumed as vegetables (like the tender shoots of Asphodeline lutea, Carlina gummifera, Clematis vitalba, and Tamus communis) or to prepare jams (such as the fruits of Rubia peregrina).

The data reported by Geraci et al. (2018) are based on interviews carried out throughout the main island of Sicily and only focused on the plants and plant portions consumed as vegetables, while c. $25 \%$ of our interviews were carried out on the circum-Sicilian islets and regarded the whole spectrum of NWFP, including 90 aromatic and fruit-bearing plant species. The same value of harvest frequency was assigned to 42 out of the 202 plants $(20.8 \%)$ of the common pool, while for 49 taxa $(24.2 \%)$ the evaluation was consistently different (2-4 points of the adopted scale). Most of the differences between the two assessments may depend on the way (total number, geographical distribution and scope) the interviews were carried out by the two research groups.

Our results point out the need of making further efforts in order to retrieve and homogenize the information already available in the gray ethnobotanical literature, mostly published in Italian on regional and local papers which are often hard to find and to consult. To overcome errors and to improve the quality and effectiveness of their researches, ethnobotanists, ethnologists, and all the skilled persons involved in wild plant harvesting should start a tighter collaboration and launch an ambitious multidisciplinary research program focused on Sicilian traditional environmental knowledge (TEK: Heckler, 2012) and edible plants' use.

In order to avoid the transfer of erroneous information, in our opinion, the international scientific community should perform a more severe review of the data concerning the human diet. 
As a rule of thumb, papers concerning edible plants should be not only written but also reviewed (and eventually rejected) by skilled local botanists in order to avoid that wrong information is published on scientific journals and reaches (and eventually kills) uninformed readers.

\section{Useful, Yet at the Brink of Oblivion}

Taking into account the worrying forecasts regarding food security for the forthcoming years due to climate warming and global change (Ford-Lloyd et al., 2011), during the last decades an increasing effort has been addressed on the detection and conservation of CWR (Valdés et al., 1997; Heywood et al., 2007; Maxted et al., 2010; Dempewolf et al., 2014). Regional and national inventories have been strongly encouraged, and seed banks are currently created and implemented (Maxted et al., 2007, 2012; Vincent et al., 2013). These efforts aim at preserving wild food plants, restoring old varieties, finding out new technologies to enhance their use and new solutions to manage modern agricultural systems (Hajjar and Hodgkin, 2007) more sustainably (Caneva et al., 2013). In this framework, we are convinced that in-depth ecological insights on NWFP may innovate and increase the spectrum of cultivated vegetables.

In the perspective of implementing sustainable agriculture under the current global change scenario, each of the 39 plants reported in Table 1, showing the most promising traits in terms of tolerance to several stress factors (water shortage, high temperatures, and edaphic constraints), could be cultivated for experimental purposes. Also, given that a considerable number of Sicilian NWFP can be considered CWR, they could be tested in ad hoc genetic improvement programs of traditional crops, like it has been already done for Allium (Odeny and Narina, 2011), Asparagus (Falavigna et al., 2008; Kanno and Yokoyama, 2011), Beta (McGrath et al., 2011), Daucus (Grzebelus et al., 2011; Iorizzo et al., 2013), Lactuca (Davey and Anthony, 2011), Vicia (Bryant and Hughes, 2011), and for many Brassicaceae (Brassica: Branca and Cartea, 2011; Diplotaxis: Pignone and Martínez-Laborde, 2011; Eruca: Pignone and Gómez-Campo, 2011) and Rosaceae (Fragaria: Hummer et al., 2011; Malus: Ignatov and Bodishevskaya, 2011; Prunus: Potter, 2011; Pyrus: Bell and Itai, 2011; Rubus: Graham and Woodhead, 2011). Moreover, further research should be focused on many speciesrich and promising families and genera of NWFP (Table 2) whose members could be used in domestication programs aiming at developing new crops: i.e., new fragrances such as thymes (e.g., Thymbra capitata and Thymus spinulosus) and other Lamiaceae such as Clinopodium nepeta, Lavandula stoechas, and Micromeria juliana, new vegetables such as several wild species of Asparagus and wild rockets (e.g., Diplotaxis spp., Erucastrum virgatum).

Any future breeding activity concerning the most promising NWFP should start from a better understanding of their ecological traits, preferring those species that may provide additional ecosystem services and belong to genera that proved to be prone to a sensitive shift of above- and below-ground biomass allocation during the domestication process (Denison, 2012; Milla et al., 2015, 2017).
Despite their potential and prominent interest, especially for future generations, most of Sicilian NWFP seem doomed to oblivion. Due to ongoing social and economic changes in the Mediterranean area, the vast majority of the last custodians of ethnobotanical knowledge are more than 70 years old. As a consequence of their aging, not only the traditional knowledge but also entire cultural landscapes - shaped by men for millennia and providing the most suitable habitat for plenty of NWFP is deemed to be lost within the next 10-20 years. We will lose most of the diversity of NWFP if we will stop eating them. Interviews to last living memories of the past cultural heritage (De Gregorio, 2008; Sottile and Genchi, 2010) are urgently needed before traditional knowledge fades forever (Quave and Saitta, 2016; Cucinotta and Pieroni, 2018), in addition to the collection and the conservation of Sicilian wild and cultivated germplasm (Hammer and Perrino, 1995; La Mantia and Pasta, 2005; Portis et al., 2005; Hammer and Laghetti, 2006; Schicchi et al., 2008; Forconi and Guidi, 2013; Marino et al., 2013).

\section{CONCLUSION}

In this paper, we provide some preliminary clues about the ecology of all Sicilian NWFP, but knowledge on this topic needs to be improved, in order to detect any discrepancy between their real frequency, their altitudinal range, their distribution pattern and their local use as a food resource. To do that, we still need to analyze the data of all the published vegetation surveys carried out in Sicily and to cover the ethnobotanical knowledge gaps in some sectors of the island.

Tightly connected with the traditional agro-pastoral practices and landscapes, many NWFP are becoming rarer and rarer as a consequence of the ongoing processes of land-use change and abandonment. The only way to maintain both TEK and NWFP is to envisage concrete and shared measures aiming at promoting the self-sustainment of traditional agro-silvopastoral practices at the European, the national and the regional level.

Humans have shaped natural landscapes worldwide since prehistoric times. However, they often succeeded to modify ecosystem services and functioning without destroying them (Kareiva et al., 2007; Willis et al., 2007). Instead of trying to come back to nature, which may result a hard and even anachronistic target (Willis and Birks, 2006), we should try to inherit and replicate the past practices combining extensive and sustainable land use with the conservation of species diversity and ecosystem services (Plieninger et al., 2006; Guarino and Pignatti, 2010). In the end, TEK in general, and NWFP use in particular, issue from a wise and dynamic combination of silvopastoral and crop farming activities, and land use practices which allowed people and landscape to co-evolve and co-occur over millennia (Mercuri et al., 2019).

We should try to learn more about the best solutions adopted by mankind throughout history, focusing on the co-evolution between weeds, plant harvesters and farmers. At the same time, we should make more efforts in order to detect and value the TEK of the last Mediterranean bio-cultural refugia (Barthel et al., 2013). 


\section{DATA AVAILABILITY STATEMENT}

All datasets generated for this study are included in the article/Supplementary Material.

\section{AUTHOR CONTRIBUTIONS}

SP, FC, and RG conceived and supervised the project. AL carried out interviews across the whole Sicilian territory and built up the revised checklist of Sicilian NWFP with the help of SP and RG. SP, CM, RG, FC, and AG analyzed and interpreted the data. SP, RG, AG, GG, CM, and FC wrote the first draft. All authors made a substantial, direct and intellectual contribution to this work. All authors approved the final version of the manuscript.

\section{FUNDING}

This research was supported by Regione Siciliana (PO FESR 2014/2020, Azione 1.1.5 -Project: Sicily Seeds: Metodologie e tecnologie innovative per il recupero, la moltiplicazione, la

\section{REFERENCES}

Albrecht, H., Cambecèdes, J., Lang, M., and Wagner, M. (2016). Management options for the conservation of rare arable plants in Europe. Bot. Lett. 163, 389-415. doi: 10.1080/23818107.2016.1237886

Aleo, M., Cambria, S., and Bazan, G. (2013). Tradizioni etnofarmacobotaniche in alcune comunità rurali dei Monti di Trapani (Sicilia occidentale). Quad. Bot. Ambientale Appl. 24, 27-48.

Angelini, P., Bianco, P., Cardillo, A., Francescato, C., and Oriolo, G. (2009). Gli Habitat in Carta Della Natura. ISPRA, Manuali e Linee Guida 49/2009: Roma.

Araus, J. L., Ferrio, J. P., Voltas, J., Aguilera, M., and Buxó, R. (2014). Agronomic conditions and crop evolution in ancient Near East agriculture. Nat. Commun 5:3953. doi: $10.1038 /$ ncomms 4953

Arcidiacono, S. (2016). Etnobotanica Etnea. Le Piante Selvatiche e l'uomo. Palermo: Danaus, 148.

Arcidiacono, S., Costa, R., Marletta, G., Pavone, P., and Napoli, M. (2010). Usi popolari delle piante selvatiche nel territorio di Villarosa (EN - Sicilia Centrale). Quad. Bot. Ambientale Appl. 21, 95-118.

Arcidiacono, S., Napoli, M., Oddo, G., and Pavone, P. (2007). Piante selvatiche d'uso popolare nei territori di alcara li fusi e militello rosmarino (Messina, N-E Sicilia). Quad. Bot. Ambientale Appl. 18, 105-146.

Atzei, D. (2003). Le Piante Nella Tradizione Popolare Della Sardegna. Sassari: C. Delfino Editore.

Barthel, S., Crumley, C. L., and Svedin, U. (2013). Biocultural refugia: combating the erosion of diversity in landscapes of food production. Ecol. Soc. 18:71. doi: 10.5751/ES-06207-180471

Bazan, G., Marino, P., Guarino, R., Domina, G., and Schicchi, R. (2015). Bioclimatology and vegetation series in sicily: a geostatistical approach. Ann. Bot. Fenn. 52, 1-18. doi: 10.5735/085.052.0202

Bell, R. L., and Itai, A. (2011). "Pyrus," in Wild Crop Relatives: Genomic and Breeding Resources: Temperate Fruits, ed. C. Kole (Berlin: Springer), 147-177.

Bharucha, Z., and Pretty, J. (2010). The roles and values of wild foods in agricultural systems. Philos. Trans. R. Soc. B 365, 2913-2926. doi: 10.1098/rstb.2010. 0123

Biscotti, N., Bonsanto, D., and Del Viscio, G. (2018). The traditional food use of wild vegetables in Apulia (Italy) in the light of Italian ethnobotanical literature. Italian Bot. 5, 1-24. doi: 10.3897/italianbotanist.5.22297

Bogaard, A., Fraser, R., Heaton, T. H. E., Wallace, M., Vaiglova, P., Charles, M., et al. (2013). Crop manuring and intensive land management by Europe's first valorizzazione e l'utilizzo di piante spontanee commestibili della flora siciliana, Grant No. 08PA6201000062). CM was supported by the grant no. 19-28491X of the Czech Science Foundation.

\section{ACKNOWLEDGMENTS}

The kind support of Francesca La Bella (IBBR-CNR, Palermo), Tommaso La Mantia and Giovanna Sala (Department of Agricultural, Food and Forest Sciences, University of Palermo) during our bibliographic research was much appreciated. We are grateful to Giovanni Salerno (Department of Environmental Biology, University of Rome III) for his advice about the best way to treat the doubtful records concerning potentially dangerous species reported as edible by other authors coping with Sicilian wild food plants.

\section{SUPPLEMENTARY MATERIAL}

The Supplementary Material for this article can be found online at: https://www.frontiersin.org/articles/10.3389/fpls.2020.00388/ full\#supplementary-material

farmers. Proc. Natl. Acad. Sci. U.S.A. 110, 12589-12594. doi: 10.1073/pnas. 1305918110

Branca, F., and Cartea, E. (2011). "Brassica," in Wild Crop Relatives: Genomic and Breeding Resources: Oilseeds, ed. C. Kole (Berlin: Springer), 17-36.

Brullo, S., and Guarino, R. (2007). The Mediterranean weedy vegetation and its origin. Ann. Bot. 7, 101-110.

Bryant, J. A., and Hughes, S. G. (2011). "Vicia”, in Wild Crop Relatives: Genomic and Breeding Resources: Legume Crops and Forages, ed. C. Kole (Berlin: Springer), 273-290.

Caneva, G., Pieroni, A., and Guarrera, P. M. (2013). Etnobotanica. Conservazione di un Patrimonio Culturale Come Risorsa per uno Sviluppo Sostenibile. Bari: Edipuglia.

Carbone, S., Di Stefano, P., Monaco, C., and Sulli, A. (2018). Sicilia e Isole Minori: Guide Geologiche Regionali. Bologna: Società Geologica Italiana.

Chase, M. W., Christenhusz, M. J. M., Fay, M. F., Byng, J. W., Judd, W. S., Soltis, D. E., et al. (2016). An update of the angiosperm phylogeny group classification for the orders and families of flowering plants: APG IV. Bot. J. Linn. Soc. 181, 1-20. doi: 10.1111/boj.12385

Coria, G. (1989). La Magia Verde. Piante Fiori ed Erbe Negli Iblei. Palermo: Publisicula, 164.

Corsi, G., and Pagni, A. M. (1979). Studi sulla flora e vegetazione del Monte Pisano (Toscana Nord-Occidentale). V. Le piante spontanee nell'alimentazione popolare. Atti. Soc. Tosc. Sci. Tat. Mem. B 86, 79-101. doi: 10.1080/00837792. 1980.10670205

Cucinotta, F., and Pieroni, A. (2018). 'If you want to get married, you have to collect virdura': the vanishing custom of gathering and cooking wild food plants on Vulcano, Aeolian Islands, Sicily. Food Cult. Soc. 21, 539-567. doi: 10.1080/ 15528014.2018.1481263

Cunniff, J., Wilkinson, S., Charles, M., Jones, G., Rees, M., and Osborne, C. P. (2014). Functional traits differ between cereal crop progenitors and other wild grasses gathered in the Neolithic fertile Crescents. PLoS One 9:e87586. doi: 10.1371/journal.pone.0087586

Davey, M. R., and Anthony, P. (2011). "Lactuca," in Wild Crop Relatives: Genomic and Breeding Resources: Vegetables, ed. C. Kole (Berlin: Springer), 115-128.

De Gregorio, N. (2008). Cibo e Parole di una Comunità di Montagna. A Cammarata con il Questionario dell'ALS:Materiali e ricerche dell'ALS n. 20. Palermo: Centro di studi filologici e linguistici siciliani, 173.

De Michele, R., La Bella, F., Gristina, A. S., Fontana, F., Pacifico, D., Garfi, G., et al. (2019). Phylogenetic relationship among wild and cultivated grapevine in Sicily: 
a hotspot in the middle of the Mediterranean Basin. Front. Plant Sci. 10:1506. doi: $10.3389 /$ fpls.2019.01506

Della, A., Paraskeva-Hadjichambi, D., and Hadjichambis, A. C. (2006). An ethnobotanical survey of wild edible plants of Paphos and Larnaca countryside of Cyprus. J. Ethnobiol. Ethnomed. 2:34. doi: 10.1186/1746-4269-2-34

Dempewolf, H., Eastwood, R. J., Guarino, L., Khoury, C. K., Müller, J. V., and Toll, J. (2014). Adapting agriculture to climate change: a global initiative to collect, conserve, and use crop wild relatives. Agroecol. Sust. Food 38, 369-377. doi: 10.1080/21683565.2013.870629

Denison, R. (2012). Darwinian Agriculture. How Understanding Evolution Can Improve Agriculture. Princeton: Princeton University Press.

Diez, C. M., Trujillo, I., Urdiroz, N. M., Barranco, D., Rallo, L., Marfil, P., et al. (2015). Olive domestication and diversification in the Mediterranean Basin. New Phytol. 206, 436-447. doi: 10.1111/nph.13181

Disciglio, G., Tarantino, A., Frabboni, L., Gagliardi, A., Giuliani, M. M., Tarantino, E., et al. (2017). Qualitative characterization of cultivated and wild edible plants: mineral elements, phenols content and antioxidant capacity. Ital. J. Agron. 12:1036. doi: 10.4081/ija.2017.1036

Falavigna, A., Alberti, P., Casali, P. E., Toppino, L., Huaisong, W., and Mennella, G. (2008). Interspecific hybridization for asparagus breeding in Italy. Acta Hortic. 776, 291-297. doi: 10.17660/ActaHortic.2008.776.37

Florenzano, A., Marignani, M., Rosati, L., Fascetti, S., and Mercuri, A. M. (2015). Are Cichorieae an indicator of open habitats and pastoralism in current and past vegetation studies? Plant Biosyst. 149, 154-165. doi: 10.1080/11263504. 2014.998311

Forconi, V., and Guidi, S. (2013). Frutti Dimenticati e Biodiversità Recuperata. Il Germoplasma Frutticolo e Viticolo Delle Agricolture Tradizionali Italiane. Casi studio: Isole Della Sicilia, Lombardia. Ispra: Quaderni Natura e Biodiversità, 136.

Ford-Lloyd, B. V., Schmidt, M., Armstrong, S. J., Barazani, O., Engels, J., Hadas, R., et al. (2011). Crop wild relatives: undervalued, underutilized and under threat? BioScience 61, 559-565. doi: 10.1525/bio.2011.61.7.10

Freschet, G. T., Swart, E. M., and Cornelissen, J. H. C. (2015). Integrated plant phenotypic response to contrasting above- and below-ground resources: key roles of specific leaf area and root mass fraction. New Phytol. 206, 1247-1260. doi: $10.1111 /$ nph. 13352

Galasso, G., Conti, F., Peruzzi, L., Ardenghi, N. M. G., Banfi, E., CelestiGrapow, L., et al. (2018). An updated checklist of the vascular flora alien to Italy. Plant Biosyst. 152, 556-592. doi: 10.1080/11263504.2018.144 1197

Gamboni, M., Carimi, F., and Migliorini, P. (2012). "Mediterranean diet: an integrated view," in Sustainable Diets and Biodiversity: Directions and Solutions for Policy, Research and Action, eds B. Burlingame and S. Dernini (Rome: Food and Agriculture Organization and Bioversity International), 262-273.

Gargano, M. L., Venturella, G., Lazzara, S., Lo Nardo, R., and Saporita, P. (2018). Ethnobotanical knowledge in some rural communities of northern Sicily (Palermo, Italy). Atti. Soc. Tosc. Sci. Nat. Mem. B 125, 31-40. doi: 10.2424/ ASTSN.M.2017.28

Geraci, A., Amato, F., Di Noto, G., Bazan, G., and Schicchi, R. (2018). The wild taxa utilized as vegetables in Sicily (Italy): a traditional component of the Mediterranean diet. J. Ethnobiol. Ethnomed. 14:14. doi: 10.1186/s13002-0180215-x

Ghirardini, M. P., Carli, M., Del Vecchio, N., Rovati, A., Cova, O., Valigi, F., et al. (2007). The importance of a taste. A comparative study on wild food plant consumption in twenty-one local communities in Italy. J. Ethnobiol. Ethnomed. 3:22. doi: $10.1186 / 1746-4269-3-22$

Giardina, G., Raimondo, F. M., and Spadaro, V. (2007). A catalogue of plants growing in Sicily. Bocconea 20:582.

Graham, J., and Woodhead, M. (2011). "Rubus," in Wild Crop Relatives: Genomic and Breeding Resources: Temperate Fruits, ed. C. Kole (Berlin: Springer), 179-196.

Gristina, A. S., Fici, S., Siragusa, M., Fontana, I., Garf, G., and Carimi, F. (2014). Hybridization in Capparis spinosa L.: molecular and morphological evidence from a Mediterranean island complex. Flora 209, 733-741. doi: 10.1016/j.flora. 2014.09.002

Grivetti, L. E., and Ogle, B. M. (2000). Value of traditional foods in meeting macroand micronutrient needs: the wild plant connection. Nutr. Res. Rev. 13, 31-46. doi: $10.1079 / 095442200108728990$
Grzebelus, D., Baranski, R., Spalik, K., Allender, C., and Simon, P. W. (2011). "Daucus," in Wild Crop Relatives: Genomic and Breeding Resources: Vegetables, ed. C. Kole (Berlin: Springer), 91-113.

Guarino, R. (2006). On the origin and evolution of the Mediterranean dry grasslands. Ber. Reinhold Tüxen Ges. 18, 195-206. doi: 10.1111/j.1365-294X. 2008.03836.x

Guarino, R., Cutaia, F., Giacopelli, A. L., Menegoni, P., Pelagallo, F., Trotta, C., et al. (2015). Disintegration of Italian rural landscapes to international environmental agreements. Int. Environ. Agreem. 17, 161-172. doi: 10.1007/ s10784-015-9310-9

Guarino, R., Giusso del Galdo, G., and Pignatti, S. (2005). The Mediterranean dwarf shrubs: origin and adaptive radiation. Ann. Bot. 5, 93-101.

Guarino, R., and Pasta, S. (2017). "Botanical Excursions in Central and Western Sicily," in Proceedings of the Field Guide for the 60th IAVS Symposium (Palermo: Palermo University Press).

Guarino, R., and Pasta, S. (2018). Sicily: the island that didn't know to be an archipelago. Ber. Reinhold Tüxen Ges. 30, 133-148.

Guarino, R., and Pignatti, S. (2010). Diversitas and biodiversity: the roots of a 21st century myth. Rendic. Lincei. Sci. Fis. Nat. 20, 351-357. doi: 10.1007/s12210010-0104-2

Guarrera, M. (1994). Il Patrimonio Etnobotanico del Lazio. Roma: Lazio Regione, Univ.La Sapienza-Dep. Biologia vegetale,Tip. Tipar.

Guarrera, P. M., and Savo, V. (2016). Wild food plants used in traditional vegetable mixtures in Italy. J. Ethnopharmacol. 185, 202-234. doi: 10.1016/j.jep.2016.02. 050

Guijt, I. (1998). "Valuing wild plants with economics and participatory methods: an overview of the Hidden Harvest methodology," in Plants for Food and Medicine, eds H. D. V. Prendergast, N. L. Etkin, D. R. Harris, and P. J. Houghton (Richmond: Royal Botanic Gardens, Kew), 223-235.

Hadjichambis, A. C. H., Paraskeva-Hadjichambi, D., Della, A., Giusti, M. E., De Pasquale, C., Lenzarini, C., et al. (2008). Wild and semi-domesticated food plant consumption in seven circum-Mediterranean areas. Intern. J. Food Sci. Nutr. 59, 383-414. doi: 10.1080/09637480701566495

Hajjar, R., and Hodgkin, T. (2007). The use of wild relatives in crop improvement: a survey of developments over the last 20 years. Euphytica 156, 1-13. doi: 10.1007/s10681-007-9363-0

Hammer, K., and Laghetti, G. (2006). Le Piccole Isole Rurali Italiane. Bari: Istituto di Genetica Vegetale C.N.R.

Hammer, K., and Perrino, P. (1995). Plant genetic resources in South Italy and Sicily - studies towards in situ and on farm conservation. Pl. Gen. Res. Newsl. 103, 19-23.

Heckler, S. (2012). Landscape, Process and Power: Re-Evaluating Traditional Environmental Knowledge. Studies in Environmental Anthropology and Ethnobiology. New York, NY: Berghahn Books.

Heywood, V. H., Casas, A., Ford-Lloyd, B., Kell, S., and Maxted, N. (2007). Conservation and sustainable use of crop wild relatives. Agr. Ecosyst. Environ. 121, 245-255. doi: 10.1016/j.agee.2006.12.014

Heywood, V. H., and Zohary, D. (1995). A catalogue of the wild relatives of cultivated plants native to Europe. An enumeration of the wild genetic resources of native European plants that are grown in Europe for food, forage, ornament, timber and other purposes. Fl. Medit. 5, 375-415.

Hummer, K. E., Bassil, N., and Njuguna, W. (2011). "Fragaria," in Wild Crop Relatives: Genomic and Breeding Resources: Temperate Fruits, ed. C. Kole (Berlin: Springer), 17-44.

Ignatov, A., and Bodishevskaya, A. (2011). "Malus," in Wild Crop Relatives: Genomic and Breeding Resources: Temperate Fruits, ed. C. Kole (Berlin: Springer), 45-64.

Iorizzo, M., Senalik, D. A., Ellison, S. L., Grzebelus, D., Cavagnaro, P. F., Allender, C., et al. (2013). Genetic structure and domestication of carrot (Daucus carota subsp. sativus) (Apiaceae). Am. J. Bot. 100, 930-938. doi: 10.3732/ajb.130 0055

ISPRA (2012). Carta Degli Habitat Alla Scala 1:50.000 Della Sicilia. Sistema Informativo di Carta della Natura. Available online at: http://www. isprambiente.gov.it/it/servizi-per-lambiente/sistema-carta-della-natura/cartadella-natura-alla-scala-1-50.000/sicilia (accessed June 11, 2019).

Kanno, A., and Yokoyama, J. (2011). “Asparagus: vegetables," in Wild Crop Relatives: Genomic and Breeding Resources, ed. C. Kole (Berlin: Springer), $23-42$. 
Kareiva, P., Watts, S., McDonald, R., and Boucher, T. (2007). Domesticated nature: shaping landscapes and ecosystems for human welfare. Science 316, 1866-1869. doi: $10.1126 /$ science. 1140170

La Mantia, T., Carimi, F., Di Lorenzo, R., and Pasta, S. (2011). The agricultural heritage of Lampedusa (Pelagie Archipelago, South Italy) and its key role for cultivar and wildlife conservation. Ital. J. Agron. 6:e17. doi: 10.4081/ija.2011.e17

La Mantia, T., and Pasta, S. (2005). "The Sicilian phanerophytes: still a noteworthy patrimony, soon a lost resource?"' in Proceedings of the Monitoring and Indicators of Forest Biodiversity in Europe - from Ideas to Operationality. I.U.F.R.O. Conference, Florence, E.F.I. Proceedings n. 51, ed. M. Marchetti (Florence: EFI), 515-526.

Leighton, R. (1999). Sicily Before History: An Archaeological Survey from the Palaeolithic to the Iron Age. London: Duckworth Publishers.

Lentini, F., and Mazzola, P. (1998). "Le piante utilizzate nella tradizione locale," in Il Popolamento Vegetale Della Riserva Dello Zingaro (Sicilia), eds F. M. Raimondo and R. Schicchi (Palermo: Azienda Foreste Demaniali Regione Siciliana), 83-134.

Lentini, F., and Venza, F. (2007). Wild food plants of popular use in Sicily. J. Ethnobiol. Ethnomed. 3:15. doi: 10.1186/1746-4269-3-15

Leonti, M., Nebel, S., Rivera, D., and Heinrich, M. (2006). Wild gathered food plants in the European Mediterranean: a comparative analysis. Econ. Bot. 60, 130-142. doi: 10.1663/0013-0001(2006)60[130:wgfpit]2.0.co;2

Licata, M., Tuttolomondo, T., Leto, C., Virga, G., Bonsangue, G., Cammalleri, I., et al. (2016). A survey of wild species for food use in Sicily (Italy): results of a 3-year study in four regional parks. J. Ethnobiol. Ethnomed. 12:12. doi: 10.1186/s13002-015-0074-7

Łuczaj, Ł., Pieroni, A., Tardío, J., Pardo de Santayana, M., Sõukand, R., Svanberg, I., et al. (2012). Wild food plant use in 21st century Europe: the disappearance of old traditions and the search for new cuisines involving wild edibles. Acta Soc. Bot. Poloniae 81, 359-370. doi: 10.5586/asbp.2012.031

Mannino, M. A., Catalano, G., Talamo, S., Mannino, G., Di Salvo, R., Catalano, G., et al. (2012). Origin and diet of the prehistoric hunter-gatherers on the Mediterranean Island of Favignana (Egadi Islands, Sicily). PLoS One 7:e49802. doi: 10.1371/journal.pone.0049802

Marino, P., Schicchi, R., Barone, E., Raimondo, F. M., and Domina, G. (2013). First results on the phenotypic analysis of wild and cultivated species of Pyrus in Sicily. Flora Medit. 23, 237-243. doi: 10.7320/FlMedit23.237

Martin-Robles, N., Morente-López, J., Freschet, G. T., Poorter, H., Roumet, C., and Milla, R. (2019). Root traits of herbaceous crops: pre-adaptation to cultivation or evolution under domestication? Funct. Ecol. 33, 273-285. doi: 10.1111/13652435.13231

Maxted, N., Ford-Lloyd, B. V., Jury, S., Kell, S., and Scholten, M. (2006). Towards a definition of a crop wild relative. Biodivers. Conserv. 15, 2673-2685. doi: 10.1007/s10531-005-5409-6

Maxted, N., Kell, S., Ford-Lloyd, B., Dulloo, E., and Toledo, Á (2012). Toward the systematic conservation of global crop wild relative diversity. Crop Sci. 52, 774-785. doi: 10.2135/cropsci2011.08.0415

Maxted, N., Kell, S., Toledo, Á, Dulloo, E., Heywood, V., Hodgkin, T., et al. (2010). A global approach to crop wild relative conservation: securing the gene pool for food and agriculture. Kew Bull. 65, 561-576. doi: 10.1007/s12225-0119253-4

Maxted, N., Scholten, M., Codd, R., and Ford-Lloyd, B. (2007). Creation and use of a national inventory of crop wild relatives. Biol. Cons. 140, 142-159. doi: 10.1016/j.biocon.2007.08.006

Mazzola, P., Nibali Lupica, S., and Bartolotta, L. (2015). Contributo alla conoscenza delle piante alimurgiche del Parco dei Nebrodi: le specie utilizzate nella tradizione popolare di Caronia (Messina). Quad. Bot. Ambientale Appl. 26, 3-10.

McGrath, J. M., Panella, L., and Frese, L. (2011). "Beta," in Wild Crop Relatives: Genomic and Breeding Resources: Industrial Crops, ed. C. Kole (Berlin: Springer), 1-28.

Médail, F., and Quézel, P. (1999). Biodiversity hotspots in the Mediterranean Basin: setting global conservation priorities. Conserv. Biol. 13, 1510-1513. doi: 10.1046/j.1523-1739.1999.98467.x

Mercati, F., Fontana, I., Gristina, A. S., Martorana, A., El Nagar, M., De Michele, R., et al. (2019). Transcriptome analysis and codominant markers development in caper, a drought tolerant orphan crop with medicinal value. Sci. Rep. 9:10411. doi: $10.1038 / \mathrm{s} 41598-019-46613-\mathrm{x}$
Mercuri, A. M., Florenzano, A., Burjachs, F., Giardini, M., Kouli, K., Masi, A., et al. (2019). From influence to impact: the multifunctional land-use in Mediterranean prehistory emerging from palynology of archaeological sites (8.0-2.8 ka BP). Holocene 29, 830-846. doi: 10.1177/0959683619826631

Milla, R., Bastida, J. M., Turcotte, M. M., Jones, G., Violle, C., Osborne, C. P., et al. (2018). Phylogenetic patterns and phenotypic profiles of the species of plants and mammals farmed for food. Nat. Ecol. Evol. 2, 1808-1817. doi: 10.1038/ s41559-018-0690-4

Milla, R., García-Palacios, P., and Matesanz, S. (2017). Looking at past domestication to secure ecosystem services of future croplands. J. Ecol. 105, 885-889. doi: 10.1111/1365-2745.12790

Milla, R., Osborne, C. P., Turcotte, M. M., and Violle, C. (2015). Plant domestication through an ecological lens. Trends Ecol. Evol. 30, 463-469. doi: 10.1016/j.tree.2015.06.006

Monello, N. (2018). Antologia. Monti Iblei, Avola, Sant'Elia. Sicily: Sebastiano Monieri Editore, 460.

Morreale, F. (2018). Piante Spontanee Alimentari in Sicilia. Guida di fitoalimurgia. Siracusa: Casa Editrice Natura Sicula.

Mucina, L., Buültmann, H., Dierssen, K., Theurillat, J.-P., Raus, T., Andraž Ėarni, A., et al. (2016). Vegetation of Europe: hierarchical floristic classification system of vascular plant, bryophyte, lichen, and algal communities. Appl. Veg. Sci. 19(Suppl. 1), 3-264. doi: 10.1111/avsc. 12257

Noti, R., van Leeuwen, J., Colombaroli, D., Vescovi, E., Pasta, S., La Mantia, T., et al. (2009). Mid- and Late-Holocene vegetation and fire history of Biviere di Gela, a coastal lake in southern Sicily. Ital. Veg. Hist. Archaeobot. 18, 371-387. doi: 10.1007/s00334-009-0211-0

Odeny, D. A., and Narina, S. S. (2011). "Allium," in Wild Crop Relatives: Genomic and Breeding Resources: Vegetables, ed. C. Kole (Berlin: Springer), 1-10.

Pasta, S., Garfi, G., La Bella, F., Rühl, J., and Carimi, F. (2011). "An overview on the human exploitation of Sicilian native edible plants," in Wild Plants: Identification, Uses and Conservation, ed. E. R. Davis (Hauppauge, NY: Nova Science Publishers Press), 195-268.

Pieroni, A., and Price, L. (2005). Eating and Healing: Traditional Food as Medicine. New York, NY: Food Products Press.

Pignatti, S., Guarino, R., and La Rosa, M. (2017-2019). Flora d'Italia, 2nd Edn, Vol. 1-4. Bologna: Edagricole.

Pignone, D., and Gómez-Campo, C. (2011). "Eruca," in Wild Crop Relatives: Genomic and Breeding Resources: Oilseeds, ed. C. Kole (Berlin: Springer), 149-160.

Pignone, D., and Martínez-Laborde, J. B. (2011). "Diplotaxis," in Wild Crop Relatives: Genomic and Breeding Resources: Oilseeds, ed. C. Kole (Berlin: Springer), 137-147. doi: 10.1007/978-3-642-14871-2_7

Plieninger, T., Höchtl, F., and Spek, T. (2006). Traditional land-use and nature conservation in European rural landscapes. Environ. Sci. Policy 9, 317-321. doi: 10.1016/j.envsci.2006.03.001

Portis, E., Mauromicale, G., Bardi, L., Mauro, M., and Lanteri, S. (2005). Population structure and genetic variation in autochthnous globe artichoke germplasm from Sicily Island. Plant Sci. 168, 1591-1598. doi: 10.1016/j.plantsci.2005.02. 009

Potter, D. (2011). "Prunus," in Wild Crop Relatives: Genomic and Breeding Resources: Oilseeds: Temperate Fruits, ed. C. Kole (Berlin: Springer), 129-145.

Provitina, F. M. (1991). Flora sicula. Dizionario trilingue illustrato. Palermo: Kefagrafica, 415.

Quave, C. L., and Saitta, A. (2016). Forty-five years later: the shifting dynamic of traditional ecological knowledge on Pantelleria Island. Ital. Econ. Bot. 70, 380-393. doi: 10.1007/s12231-016-9363-x

Ranfa, A., Maurizi, A., Romano, B., and Bodesmo, M. (2014). The importance of traditional uses and nutraceutical aspects of some edible wild plants in human nutrition: the case of Umbria (central Italy). Plant Biosyst. 148, 297-306. doi: 10.1080/11263504.2013.770805

Reich, P. B. (2014). The world-wide "fast-slow" plant economics spectrum: a traits manifesto. J. Ecol. 102, 275-301. doi: 10.1111/1365-2745. 12211

Renna, M. (2017). Wild edible plants as a source of mineral elements in the daily diet. Progr. Nutr. 19, 219-222. doi: 10.23751/pn.v19i2.5662

Rivera, D., Obón, C., Heinrich, M., Inocencio, C., Verde, A., and Fajardo, J. (2006). "Gathered mediterranean food plants. Ethnobotanical investigations and historical development," in Local Mediterranean Food Plants and 
Nutraceuticals. Forum Nutr, eds M. Heinrich, W. E. Müller, and C. Galli (Basel: Karger), 18-74. doi: 10.1159/000095207

Sadori, L., Zanchetta, G., and Giardini, M. (2008). Last glacial to Holocene palaeoenvironmental evolution at Lago di Pergusa (Sicily, southern Italy) as inferred by pollen, microcharcoal, and stable isotopes. Quat. Internat. 181, 4-14. doi: 10.1016/j.quaint.2007.02.024

Schaffer, S., Schmitt-Schillig, S., Müller, W. E., and Eckert, G. P. (2005). Antioxidant properties of Mediterranean food plant extracts: geographical differences. J. Physiol. Pharmacol. 56, 115-124.

Schicchi, R., and Geraci, A. (2016). Verdure Spontanee di Sicilia. Guida al Riconoscimento, alla Raccolta e alla Preparazione. Palermo: IDIMED.

Schicchi, R., Geraci, A., and Marino, P. (2008). Genetic diversity on Pyrus L. (Rosaceae) in Sicily. Bocconea 23, 141-146.

Signorello, P. (2015). Piante Spontanee Siciliane Mangerecce E Velenose. Acireale: Stampa Massimino, 191.

Simopoulos, A. P. (2004). Omega-3 fatty acids and antioxidants in edible wild plants. Biol. Res. 37, 263-277. doi: 10.4067/s0716-97602004000200013

Snir, A., Nadel, D., Groman-Yaroslavski, I., Melamed, Y., Sternberg, M., BarYosef, O., et al. (2015). The origin of cultivation and proto-weeds, long before Neolithic farming. PLoS One 10:e0131422. doi: 10.1371/journal.pone. 0131422

Sottile, R., and Genchi, M. (2010). Lessico Della Cultura Dialettale Delle Madonie. 1. Lalimentazione. Centro di Studi Filologici e Linguistici Siciliani-Dipartimento di Scienze Filologiche e Linguistiche. Palermo: L'ALS per la scuola e il territorio.

Stika, H.-P., Heiss, A. G., and Zach, B. (2008). Plant remains from the early Iron Age in western Sicily: differences in subsistence strategies of Greek and Elymian sites. Veg. Hist. Archaeobot. 17, 139-148. doi: 10.1007/s00334-0080171-9

ter Braak, C. J. F., and Smilauer, P. (2012). CANOCO Reference Manual and User's Guide: Software for Ordination (Version 5.0). Ithaca, NY: Microcomputer Power.

Tinner, W., van Leeuwen, J. F. N., Colombaroli, D., Vescovi, E., van der Knaap, P. W. O., Henne, P. D., et al. (2009). Holocene environmental and climatic changes at Gorgo Basso, a coastal lake in southern Sicily. Italy. Quat. Sci. Rev. 28, 1498-1510. doi: 10.1016/j.quascirev.2009.02.001

Tinner, W., Vescovi, E., van Leeuwen, J. F. N., Colombaroli, D., Henne, P. D., Kaltenrieder, P., et al. (2016). Holocene vegetation and fire history of the mountains of Northern Sicily (Italy). Veg. Hist. Archeobot. 25, 499-519. doi: 10.1007/s00334-016-0569-8

Triboullois, H., Fort, F., Cruz, P., Charles, R., Flores, O., Garnier, E., et al. (2015). A functional characterisation of a wide range of cover crop species: growth and nitrogen acquisition rates, leaf traits and ecological strategies. PLoS One 10:e0122156. doi: 10.1371/journal.pone.0122156

Trichopoulou, A., Vasilopoulou, E., Holiman, P., Chamalides, C., Foufa, E., Kaloudis, T., et al. (2000). Nutritional composition and flavonoid content of edible wild greens and green pies: a potential rich sources of antioxidant nutrients in the Mediterranean diet. Food Chem. 70, 319-323. doi: 10.1016/ S0308-8146(00)00091-1
Tuttolomondo, T., Licata, M., Leto, C., Bonsangue, G., Gargano, M. L., Venturella, G., et al. (2014a). Popular uses of wild plant species for medicinal purposes in the Nebrodi regional park (North-Eastern Sicily, Italy). J. Ethnopharmacol. 157, 21-37. doi: 10.1016/j.jep.2014.08.039

Tuttolomondo, T., Licata, M., Leto, C., Gargano, M. L., Venturella, G., and La Bella, S. (2014b). Plant genetic resources and traditional knowledge on medicinal use of wild shrub and herbaceous plant species in the Etna regional park (Eastern Sicily, Italy). J. Ethnopharmacol. 155, 1362-1381. doi: 10.1016/j.jep.2014.07.043

Valdés, B., Heywood, V. H., Raimondo, F. M., and Zohary, D. (1997). Proceedings of the workshops on 'Conservation of the wild relatives of European cultivated plants'. Bocconea 7, 1-479.

Vincent, H., Wiersema, J., Kell, S., Fielder, H., Dobbie, S., Castañeda-Álvarez, N. P., et al. (2013). A prioritized crop wild relative inventory to help underpin global food security. Biol. Cons. 167, 265-275. doi: 10.1016/j.biocon.2013.08.011

Viruel, J., Galliot, N., Pironon, S., Feliner, G., Suc, J.-P., Lakhal, M. F., et al. (2019). Astrong east-west Mediterranean divergence supports a new phylogeographic history of the carob tree (Ceratonia siliqua, Leguminosae) and multiple domestications from native populations. J. Biogeogr. 47, 460-471. doi: 10.1111/ jbi.13726

Vitasović Kosić, I., Juračak, J., and Łuczaj, Ł (2017). Using Ellenberg-Pignatti values to estimate habitat preferences of wild food and medicinal plants: an example from northeastern Istria (Croatia). J. Ethnobiol. Ethnomed. 13, 2-19. doi: 10.1186/s13002-017-0159-6

Willett, W. C. (2006). The Mediterranean diet: science and practice. Public Health Nutr. 9, 105-110. doi: 10.1079/phn2005931

Willis, K. J., Araújo, M. B., Bennett, K. D., Figueroa-Rangel, B., Froyd, C. A., and Myers, N. (2007). How can a knowledge of the past help to conserve the future? Biodiversity conservation and the relevance of long-term ecological studies. Philos. Trans. R. Soc. B 362, 175-187. doi: 10.1098/rstb.2006.1977

Willis, K. J., and Birks, H. J. B. (2006). What is natural? The need for a longterm perspective in biodiversity conservation. Science 314, 1261-1265. doi: 10.1126/science. 1122667

Xu, L., Freitas, S. M. A., Yu, F.-H., Dong, M., Anten, N. P. R., and Werger, M. J. A. (2013). Effects of trampling on morphological and mechanical traits of dryland shrub species do not depend on water availability. PLoS One 8:e53021. doi: 10.1371/journal.pone.0053021

Conflict of Interest: The authors declare that the research was conducted in the absence of any commercial or financial relationships that could be construed as a potential conflict of interest.

Copyright (C) 2020 Pasta, La Rosa, Garfi, Marcenò, Gristina, Carimi and Guarino. This is an open-access article distributed under the terms of the Creative Commons Attribution License (CC BY). The use, distribution or reproduction in other forums is permitted, provided the original author(s) and the copyright owner(s) are credited and that the original publication in this journal is cited, in accordance with accepted academic practice. No use, distribution or reproduction is permitted which does not comply with these terms. 